\title{
Developments
}

\section{The European Private Company: The Current Situation}

\author{
By Rolandino Guidotti
}

\section{A. Introduction}

The goal of the European Union is not only to harmonize the different national legislations but also to create new company models. These new company models are not intended to replace the national models, but instead to offer a new and free choice to business operators in addition to the national models. ${ }^{1}$ It is predictable that among these models will be the European Private Company (Societas Privata Europaea or SPE) regulated by the Proposal for a Council Regulation (presented by the Commission) of 25 June 2008. ${ }^{2}$ The other preceding European legal forms have been the European Economic Interest Grouping (EEIG) of 1985, the European Company (SE) of 2001 and the European Cooperative Society (SCE) of 2003.

As you can read in the Explanatory Memorandum, related to the Proposal, ${ }^{3}$ the initiative creates a new European legal form intended to enhance the competitiveness of small and medium-sized enterprises, by facilitating their establishment and operation in the Single Market.

\footnotetext{
*Aggregate Professor of Business Law at the University of Bologna, Italy. E-mail: rolandino.guidotti@unibo.it.

${ }^{1}$ The subject is introduced in this way by Giuseppe Zanarone, Della Società a Responsabilità Limitata, in CommentaRIo Al Codice Civile, 149 (Francesco D. Busnelli ed., 2010).

${ }^{2}$ See Commission Proposal for a Council Regulation on the Statute for a European Private Company, COM (2008) 396 final (25 June 2008); see also Paolo Santella, La Società Privata Europea, in Prospettive Del DiRitto Societario EUROPEO 290 (Giuseppe Ferri Jr. \& Mario Stella Richter Jr. eds., 2010); Roberto Weigmann, Il progetto di Statuto di una Società Privata Europea, in DotTRINA e ATtUAlità GIURIDICHE Nel DiRITTO CIVILE 99 (Pietro Rescigno et al. eds., 2010); Niek Zaman et al., The European Private Company (SPE) - A Critical Analysis of the EU Draft Statute (2009); Susanne Braun, The European Private Company: A Supranational Company Form for Small and Medium-Sized Enterprises?, 11 GeRMAN L.J. 1393 (2004); Robert Drury, The European Private Compay, 9 EUR. BUS. ORG. L. REV. 125 (2008); Jorge A. Viera Gonzales, La societad Privada Europea: Una Alternativa a la Sociedad de Responsabilidad Limitada, 5 ReVISTA DE DeRECHO MERCANTIL 1331 (2008); Daniel Kornack, The European Private Company-Entering the Scene or Lost in Discussion, 8 GERMAN L.J. 1321 (2009); Federico Tassinari, II Progetto di Regolamento in Materia di Società Privata Europea (SPE) Elaborato dalla Commissione Europea, 4 QUADERNI TRIMESTRALI DEL CONSIGLIO NAZIONALE DEL NOTARIATO 1489 (2008); Sandra van den Braak, The European Private Company, Its Shareholders and Its Creditors, 1 UTRECHT L. REV. 1, 1 (2010)

${ }^{3}$ Commission Proposal for a Council Regulation on the Statute for a European Private Company, supra note 2.
} 
Small and medium-sized enterprises account for more than $99 \%$ of companies in the European Union, but only $8 \%$ of them engage in cross-border trade (and only $5 \%$ have subsidiaries or joint ventures abroad ${ }^{4}$ )-it is necessary to finalize the rules to improve the access of small and medium-sized enterprises to the Single Market to encourage their growth.

The Explanatory Memorandum states that the Proposal also aims to reduce compliance costs for the creation and operation of businesses. These increased costs arise from disparities between national rules-both on the formation and on the operation of companies.

The Proposal is based on Art. 308 of the EC Treaty. ${ }^{5}$ This article permits the Council to adopt the appropriate measures to attain one of the objectives set out in the Treaties, if the Treaties have not provided the necessary powers. In this last case, the Council shall adopt the appropriate measures, only acting unanimously on a proposal from the Commission and after obtaining the consent of the European Parliament.

The initial idea about the European Private Company relates back to the 1990 s. $^{6}$ In the beginning, it was an initiative popular in business and academic circles. ${ }^{7}$ The preliminary project elaborated in 1998 by the Paris Chambre de Commerce et Industrie, was very important because it was systemic and created a wider debate. ${ }^{8}$

The Proposal of 25 June 2008 is accompanied by an Impact Assessment. ${ }^{9}$ The Proposal is: (1) a measure (for the period 2003-09) of the Commission's Action Plan on Modernizing Company Law and Enhancing Corporate Governance ${ }^{10}$ and (2) a part of the Single Market Review. $^{11}$ Furthermore, it is one of the key features of the Commission's Small Business

\footnotetext{
${ }^{4}$ Id.

${ }^{5}$ Consolidated Version of the Treaty on the Functioning of the European Union art. 352, 9 May 2008, 2008 O.J. (C 115) 47,196

${ }^{6}$ Prior to this period, see JeANne Boucourechliev, Pour une SARL EuropéenNe (1973).

${ }^{7}$ Van den Braak, supra note 2, at 1. See also Harm-JAN De KLUiver \& Walter VAN Gerven, The European Private COMPANY? (1995).

8 See La Société privée européenne, CHAMBRE DE COMMERCE ET D'INDUSTRIE DE PARIS, http://www.etudes.ccip.fr/dossier/15-la-societe-privee-europeenne.

${ }^{9}$ Commission Staff Working Document accompanying the Proposal for a Council Regulation on the Statute for a European Private Company, SEC (2008) 2098 final (25 June 2008).

${ }^{10}$ Modernising Company Law and Enhancing Corporate Governance in the European Union-A Plan to Move Forward, COM (2003) 284 final (21 May 2003).

${ }^{11}$ A Single Market for 21st Century Europe, COM (2007) 724 final (20 Nov. 2011).
} 
Act of 2008, which was announced in November 2007. The goal of the Small Business Act is to make the Single Market accessible to small and medium-sized enterprises. ${ }^{12}$

We can recall that as early as December 2005 a feasibility study on the SPE was published. ${ }^{13}$ The Legal Affairs Committee of the European Parliament held a public hearing on the SPE in June 2006. The same Committee issued its own initiative report, endorsed by the European Parliament in February 2007, calling for a Proposal by the Commission for a SPE. ${ }^{14}$

In addition to two public consultations, which were conducted between July and November 2007, the Directorate General for Internal Market and Services organized a public conference in March 2008 during which the principal options for a SPE were examined. The Proposal was approved by the European Parliament on 10 March 2009. Among the 72 amendments to the text of Council, ${ }^{15}$ only those considered very important will be addressed in this paper.

A total of eight compromise proposals of the Presidency of the Council of the European Union have been submitted, but none have been successful. These compromise proposals have principally focused on the seat of the company and the cross-border component, ${ }^{16}$ the minimum capital requirement, ${ }^{17}$ and the employee participation; ${ }^{18}$ space does not permit a complete analysis of each proposal in this article.

After the failure of the French Presidency to find a compromise, ${ }^{19}$ the Czech Presidency continued working on this topic with a new compromise proposal. ${ }^{20}$ There were three

\footnotetext{
12 "Think Small First" a "Small Business Act" for Europe, COM (2008) 394 final (25 June 2008).

${ }^{13}$ Feasibility Study for a European Statute for SMEs Executive Summary, EUROPEAN COMMISSION (2005), available at http://ec.europa.eu/enterprise/policies/sme/files/craft/doc/spe_feasibility_executive_summary_2005_en.pdf.

${ }^{14}$ Report with Recommendations to the Commission on the European Private Company Statute, EUR. PARL. Doc. A60434/2006, available at http://www.europarl.europa.eu/sides/getDoc.do?pubRef=//EP//NONSGML+REPORT+A6-2006-0434+0+DOC+PDF+V0//EN.

${ }^{15}$ Statute for a European Private Company, EUR. PARL. DOC. (COM 396) (2008).

${ }^{16}$ See infra Part B.

${ }^{17}$ See infra Part E.

${ }^{18}$ See infra Part $\mathrm{H}$.

${ }^{19}$ Presidency Compromise Proposal for a Council Regulation on the Statute for a European Private Company (SPE) No. 17152/08 of 11 Dec. 2008, available at http://register.consilium.europa.eu/pdf/en/08/st17/st17152.en08.pdf.
} 
subsequent Compromise Proposals of the Swedish Presidency in November $2009 .^{21}$ After the failure of the preceding Presidencies of the French, Czech and Swedish, the Hungarian Presidency, also, tried to find a compromise with three new proposals. The first one was in March 2011, ${ }^{22}$ the second ${ }^{23}$ and the third ${ }^{24}$ were in May 2011.

The last one on 30 May 2011 was not successful because Sweden did not agree to the Hungarian solution about employee participation ( $\S$ I) and Germany objected to the Hungarian solution about the seat of the company and the cross-border component (which will be analyzed in the following section). The compromise text failed to secure the unanimity required for the proposal to be approved. ${ }^{25}$

\section{B. The Seat of the Company and the Cross-Border Component}

One of the principal innovations of the Proposal on 25 June 2008 is the fact that this new legal form is not obliged to have (from the moment of formation) relationships with at least two member states. This is the case for the European Economic Interest Grouping (EEIG), ${ }^{26}$ the European Company (Societas Europaea, SE), ${ }^{27}$ and the European Cooperative Society (SCE). ${ }^{28}$

\footnotetext{
${ }^{20}$ Proposal for a Council Regulation on the Statute for a European Private Company (SPE), Revised Presidency Compromised Proposal No. 9065/09 of 27 April 2009, http://register.consilium.europa.eu/pdf/en/09/st09/st09065.en09.pdf.

${ }^{21}$ Preparation of the Council Meeting ("Competitiveness") on 3-4 December 2009 - Proposal for a Council Regulation on a European Private Company (SPE) No. 15355/09 of 9 Nov. 2009, available at http://register.consilium.europa.eu/pdf/en/09/st15/st15355-ad01.en09.pdf; Preparation of the Council meeting ("Competitiveness") on 3-4 December 2009 - Proposal for a Council Regulation on a European Private Company (SPE) No. 16155/09 of 20 Nov. 2009, available at http://register.consilium.europa .eu/pdf/en/09/st16/st16155ad01.en09.pdf; Proposal for a Council Regulation on a European Private Company - Political Agreement No. 16115/09 of 27 Nov. 2009, available at http://register.consilium.europa.eu/pdf/en/09/st16/st16115ad01.en09.pdf.

22 Proposal for a Council Regulation on a European Private Company - Political Agreement No. 8084/11 of 25 March 2011, available at http://register.consilium.europa.eu/pdf/en/11/st08/st08084.en11.pdf.

${ }^{23}$ Proposal for a Council Regulation on a European Private Company No. 10129/11 of 12 May 2011, available at http://register.consilium.europa.eu/pdf/en/11/st10/st10129.en11.pdf.

${ }^{24}$ Proposal for a Council Regulation on a European Private Company - Political Agreement No. 10611/11 of 23 May 2011, available at http://register. consilium.europa.eu/pdf/en/11/st10/st10611.en11.pdf.

${ }^{25}$ Consolidated Version of the Treaty on the Functioning of the European Union art. 352, 9 May 2008, 2008 O.J. (C 115) $47,196$.

${ }^{26}$ Council Regulation 2137/1985/EC, 1985 O.J. (L 199) 1, 3 (EC).

${ }^{27}$ Council Regulation 2157/2001/EC, 2001 O.J. (L 294) 1, 4 (EC).

${ }^{28}$ Council Regulation 1435/2003, 2003 O.J. (L 207) 1, 15-21 (EC).
} 
The proposal is limited to requiring that "[a]n SPE shall have its registered office and its central administration or a principal place of business in the Community" and that "[a]n SPE shall not be under any obligation to have its central administration or principal place of business in the Member State in which it has its registered office." 29

On 10 March 2009, the Parliament proposes the insertion of a cross-border vocation as a prerequisite for the creation of the company itself. This objective shall be attained with the addition of a new point (ea) in $\S 1$ of Art. 3 of the text proposed by the Commission.

In the opinion of the Parliament, the cross-border component is demonstrated by one of the following: (1) "a cross-border business intention or corporate object"; (2) "an objective to be significantly active in more than one Member State; establishments in different Member States"; or (3) "a parent company registered in another Member State." 30

The Parliament states that the cross-border component should not be an obstacle for the founding of a European Private Company. ${ }^{31}$ In this context, the Parliament proposes that the Commission and Member States should, within two years of registration, conduct ex post monitoring in order to examine whether the SPE has the required cross-border component. However, this is without prejudice to the requirements of registration. ${ }^{32}$

There is a contrasting idea which states that, for the success of the SPE, it would be useful if this proposal of the Parliament was not accepted. ${ }^{33}$ The reason is because, for example, if the proposal was rejected, the new SPE form could be used by companies which have operated in only one Member State for many years.

The ultimate goal of the SPE Proposal is to create an organizational vehicle that conducts its business beyond national borders. However, in its Proposal of 25 June 2008, the European Commission decided not to subject the creation of a SPE to a prior cross-border requirement. This is because this cross-border requirement could discourage the adoption

\footnotetext{
${ }^{29}$ Commission Proposal for a Council Regulation on the Statute for a European Private Company, supra note 2, at 17.

${ }^{33}$ Alessandra Zanardo \& Rolandino Guidotti, La società Cooperativa Europea (SCE) e il Progetto di Società Privata Europea (SPE), in Percorsi di DiRItTo Societario Europeo 166, 168 (Elisabetta Pederzini ed., 2011).
} 
of the vehicle and narrow the expected scope of the instrument. ${ }^{34}$ In short, a cross-border vocation as a prerequisite for the creation of the company conflicts with the original spirit of the Proposal.

The cross-border vocation of the European Private Company can be further improved with the adoption of amendment n. 62 of the Parliament. This amendment proposes, inter alia, the introduction of the Art. 42 bis according to which "[t]he articles of association may, in the form of an arbitration clause, provide for the referral to arbitrators of any disputes arising between shareholders, or between shareholders and the SPE, concerning its corporate relations." $^{\prime 35}$ The articles of associations may also provide that the arbitration clause cover disputes with the directors. In that case, the arbitration clause shall be binding on the directors upon their acceptance of the position. ${ }^{36}$

The adoption of this amendment can improve the cross-border vocation of the European Private Company because, in transnational relationships, arbitration permits the resolution of problems related to jurisdiction at their origin. Arbitration is not part of the State system of courts.

The arbitration permits in addition the selection of arbitrators with an appropriate degree of expertise in company law. ${ }^{37}$

\section{The Governing Rules}

An SPE is governed by the Regulation which is the object of this text. It is also governed by the articles of association. ${ }^{38}$ The Regulation establishes the conditions governing the creation and operation within the Community of companies in the form of a European Private Company with limited liability. ${ }^{39}$ There are forty-eight articles in the Regulation.

\footnotetext{
${ }^{34}$ Jeorge Feliu Rey \& Teresa Rodríguez de las Heras Ballell, The European Private Company: A Firm Step Forward (and Some Unsteady Steps Backwards), in the Corporate Law Flexibilization Process in Europe, 2 CONTRATTO E IMPRESA EUROPA 526, 546 (2011).

${ }^{35}$ See Resolution on the Proposal for a Council Regulation on the Statute for a European Private Company, supra note 31.

${ }^{36}$ Any amendment of the constituent act, introducing or removing the arbitration clause by a resolution of the shareholders, must be approved by shareholders representing at least two-thirds of the share capital. Id.

${ }^{37}$ Settlement of a dispute by arbitration is often faster and cheaper than litigation in courts. Arbitral proceedings can be kept confidential because arbitration is a private procedure.

${ }^{38}$ Zaman, supra note 2, at 45.

${ }^{39}$ Commission Proposal for a Council Regulation on the Statute for a European Private Company, supra note 2, at 15.
} 
The goal seems to be the creation of a self-standing regulation. But at the same time, some matters must be governed by the articles of association. These elements are indicated in the Annex I; there is ample room for discretion. The Regulation prescribes these matters and includes the internal organization of the SPE. ${ }^{40}$ The matters not governed by either the Regulation or by the articles of association, under the provisions of Art. 4 (Rules applicable to an SPE) § 1, are regulated "by the law, including the provisions implementing Community law, which applies to private limited-liability companies in the Member State in which the SPE has its registered office." The matters that must (or should) be disciplined by the articles of association (according to Annex I) are not subject to the law of the nation in which the company is registered.

The Proposal on the 25 June 2008 does not contain any default provisions which apply in the case that the articles of association do not cover the matters listed in Annex I. The national law will be called upon to regulate in this case. ${ }^{41}$

\section{The Formation and the Capital}

As you can read in the seventh Recital, ${ }^{42}$ the SPE should be capable of being created ex nihilo, even unilaterally, both by physical persons and juridical persons, according to the requirements of the Regulation.

The SPE could be created by way of transformation, merger or division of existing national companies. The formation of an SPE by way of transformation, merger or division of companies should be governed by the national law applicable to the transforming company, to each of the merging companies or to the dividing company. ${ }^{43}$

The capital of the SPE shall be expressed in euro. ${ }^{44}$ The capital shall be fully subscribed but the shares do not need to be fully paid at the moment of issue. ${ }^{45}$ "The shareholders must

\footnotetext{
${ }^{40}$ Id. at 37-39.

${ }^{41}$ See Commission Proposal for a Council Regulation on the Statute for a European Private Company, supra note 2, at 6.

${ }^{42}$ See Id. at 12 .

${ }^{43}$ Id. at 17.

${ }^{44}$ But without prejudice to art. 42, according to which, "Member States in which the third phase of economic and monetary union (EMU) does not apply may require SPEs having their registered office in their territory to express their capital in national currency. An SPE may also express its capital in euro."

${ }^{45}$ Id. at 23.
} 
pay the agreed consideration in cash or provide the agreed consideration in kind in accordance with the articles of association." ${ }^{46}$

The articles of association also regulate if the company is obliged to hold reserves. ${ }^{47}$ In the affirmative case, the articles shall define the reserves and the cases in which these reserves shall be distributed.

In order to facilitate start-ups, the Proposal "departs from the traditional approach that considers the requirements of a high minimum of legal capital as a means of creditor protection." $^{48}$ The Proposal states that the capital shall be at least one euro. ${ }^{49}$ This is because studies ${ }^{50}$ show that creditors nowadays look at aspects other than capital (such as cash flow). These are determined to be more relevant to the solvency of the company. Moreover, continues the Explanatory Memorandum, "companies have different capital needs depending on their activity, and thus it is impossible to determine an appropriate capital for all companies."

According to the Proposal, it is possible that the articles of association should state that the management body sign a "solvency certificate" which guarantees to creditors that they would be paid as they become due in the normal course of business. This shall take place within one year of the date of distribution to the shareholders. ${ }^{51}$

In the opinion of the Parliament, the capital of the SPE can be at least one euro, "provided that the articles of association require that the executive management body sign a solvency certificate as referred to in article 21." ${ }^{52}$ Where the articles of association contain no provision to that effect, the capital of the SPE shall be at least 8,000 euro. This solvency

\footnotetext{
${ }^{46}$ Id.

${ }^{47}$ Id.

${ }^{48}$ Id. at 7.

${ }^{49}$ Id. at 23.

${ }^{50}$ Luca Enriques \& Jonathan Macey, Creditors Versus Capital Formation: The Case Against the European Legal Capital Rules, 86 CORNELL L. REv. 1165 (2001); Luca Enriques, Capitale sociale, informazione Contabile e Sistema del netto: una Risposta a Francesco Denozza, 5 GIURISPRUDENZA COMMERCIALE 607 (2005).

${ }^{51}$ Commission Proposal for a Council Regulation on the Statute for a European Private Company, supra note 2, at 23.

${ }^{52}$ See Commission Proposal for a Council Regulation on the Statute for a European Private Company, supra note 2.
} 
certificate obliges the directors to assume personal responsibility to creditors in the event of a false declaration. ${ }^{53}$

\section{E. The Shares}

The articles of association must contain "the names and addresses of the founding shareholders of the SPE and the nominal value or accountable par of the shares held by them." ${ }^{54}$ The management body shall draw up a list of shareholders. The list shall contain, in addition to the name and address of each shareholder, "the amount of each consideration in cash, if any, paid or to be paid by the shareholder concerned" and "the value and nature of each consideration in kind, if any, provided or to be provided by the shareholder concerned." ${ }^{55}$

It is understood that the list of shareholders, and any amendments thereto, shall be kept by the management body. It is less obvious that the list of shareholders may be inspected by the shareholders or third parties on request. ${ }^{56}$ All agreements on the transfer of shares shall be in written form. ${ }^{57}$ Any transfer of shares shall become effective as follows: (1) in relation to the company on the day the shareholder notifies the SPE of the transfer; or (2) in relation to third parties, on the day the new shareholder is entered in the list. ${ }^{58}$ On notification of a transfer, the management body shall, without undue delay, enter the shareholder in the list referred to in Art. $15 .^{59}$

The Parliament wants to amend this rule by requiring publication of the share's transfer in a public register. The Parliament proposed, in fact, in March 2009, that any transfer of shares shall become effective, in relation to third parties, either (1) on the day the new shareholder is entered in the list referred to art. 15; or (2) on the day the transfer is

\footnotetext{
${ }^{53}$ Weigmann, supra note 2, at 109; van den Braak, supra note 1, at 2; Jaap Barneveld, Legal Capital and Creditor Protection - Some Comparative Remarks, in Zaman et. al. eds., THE EUROPEAN PRIVATE COMPANy (SPE) (note 2) 81; Kornak (note 2) 1324.

${ }^{54}$ Commission Proposal for a Council Regulation on the Statute for a European Private Company, supra note 2, at 37.

${ }^{55}$ Id. at 21.

${ }^{56} / d$.

${ }^{57} / d$.

${ }^{58} / d$.

${ }^{59}$ Id.
} 
published in the register in accordance with Art. 9 (in a register designated by the applicable national law in accordance with the art. 3 of the directive 68/151/EEC). ${ }^{60}$

The SPE shall not, directly or indirectly, subscribe its own shares, ${ }^{61}$ but the company may buy its own shares. ${ }^{62}$ The articles of association shall regulate "whether the acquisition of own shares is permitted and, if permitted, the procedure to be followed, including the conditions under which the shares may be held, transferred or cancelled."63

\section{F. The Resolution of Shareholders}

The flexibility of the juridical rule of the SPE can also be seen through the organization of the company: only the management body is indispensable for the functioning of the company. $^{64}$ The adoption of resolutions, to which we will refer below, does not require the organization of a general meeting. It is only necessary that the management body provides all shareholders with the proposals for resolutions, together with sufficient information to enable them to make an informed decision. ${ }^{65}$

Resolutions shall be recorded in writing and copies of the decisions taken shall be sent to every shareholder. ${ }^{66}$ Article $27, \S 1$, lists a series of matters that shall be decided upon by a resolution of the shareholders, by a majority as defined in the articles of association of the SPE; a majority that, for some matters, can be determined by contract.

These decisions are the approval of the annual accounts and the distribution to the shareholders. $^{67}$ Also included are the acquisition of its own shares; the redemption of shares; and the increase of share capital (but not the reduction of share capital that requires a qualified majority). Finally, there are the appointment and removal of directors

${ }^{60}$ Resolution on the Proposal for a Council Regulation on the Statute for a European Private Company, supra note 31.

${ }^{61}$ Commission Proposal for a Council Regulation on the Statute for a European Private Company, supra note 2, at 24.

62 In Italian law, under no circumstances can the limited liability company give or accept its own quotas in guaranty, or can grant loans or issue guaranties for their acquisition or their subscription. See Art. 2472 Codice civile [C.c.] (It.).

${ }^{63}$ Commission Proposal for a Council Regulation on the Statute for a European Private Company, supra note 2, at 38.

${ }^{64}$ Id. at 25 .

${ }^{65}$ Id. at 26.

${ }^{66} / d$.

${ }^{67}$ Id. 
and their terms of office, and the appointment and removal of the auditor (obviously where the SPE has an auditor).

Other decisions must be taken by a majority of shareholders, but, in this case, a qualified majority is necessary. This is equal to "two-thirds of the total voting rights attached to the shares issued by the SPE" ${ }^{68}$-the articles of association therefore can provide for a qualified majority that is more severe than that indicated above.

These last resolutions - those that must be taken by a majority that cannot be less than two-thirds of the total voting rights - are the variation of rights attaching to shares; the expulsion of a shareholder; and the withdrawal of a shareholder. Also included are the reduction of share capital (but not the increase of share capital); the transformation on the SPE; and the mergers and the divisions.

Finally, there are the transfer of the registered office of the SPE to another Member State, the winding up, and the amendments to the articles of association (not covering matters mentioned in Art. 27). According to Art. 28 of the Proposal for a Council Regulation, the shareholders shall have the right to be duly informed and to ask questions to the management body about resolutions, annual accounts and all other matters relating to activities of the SPE. The management body may refuse to give access to the information only if doing so could cause serious harm to the business interest of the SPE.

The information rights described in Art. 28 are only in relation to voting for the resolution listed in Art. 27. The articles of association shall regulate "the procedure and time limits for the SPE to respond to requests from shareholders for information, to grant access to the documents of SPE, and to notify resolutions that have been adopted by shareholders." 69

\section{G. The Directors}

According to the Proposal of 25 June 2008, only a natural person may be a director of a SPE. $^{70}$ It is possible for the SPE to choose a management body composed of one director or a management body composed of more directors; an administrative board (unitary board); or a management board (dual board). ${ }^{71}$ The management body may exercise all

\footnotetext{
${ }^{68}$ Id.

${ }^{69}$ Id. at 38 .

${ }^{70} / d$. at 28.

${ }^{71} / d$. at 38
} 
the powers not reserved to the shareholders (by the Proposal or by the articles of association). ${ }^{72}$

The power of representation of the directors is general. If the articles of association provide that the power of representation must be exercised jointly, this limitation of the power of representation may be relied on against third parties. Any other limitation to the power of the directors may not be relied on against third parties, even if they have been disclosed. $^{73}$

The directors shall be liable to the company for any act or omission in breach of duties deriving from the Regulation, the articles of association, or a resolution of the shareholders. If the breach is committed by more than one director, the Regulation provides for joint and several liability. ${ }^{74}$

The standard of care and skill required is that which can be reasonably requested in conduct of the business. ${ }^{75}$ The director shall avoid any situation that can be regarded as likely to give rise to any actual or potential conflict of interest. ${ }^{76}$ The Regulation can provide that the articles of association may authorise such a conflict, and the requirements and procedures for the authorization.

According to Art. $30 \S 2$, a person who acts as a director without having been formally appointed ("de facto director"), shall be considered a director with respect to all duties and liabilities to which the latter is subject. The Proposal for a Council Regulation presented by the Commission excludes the fact that the shareholders, who do not participate in the management of the company, have rights of control. The Proposal excludes the fact that the shareholders have the right to be informed by the directors about the performance of the company's activities or to consult, even through entrusted professionals, the company's registers and documents related to management. This matter-that of rights of control-does not appear to be regulated by the articles of association, because the intervention of the contract is limited to the matters listed in the Annex I. Among these matters we do not see regulation of the rights of control (different from that of Art. 28).

The Proposal does not provide for the possibility of an action of liability against the directors by an individual shareholder. For the European Private Companies that are

\footnotetext{
${ }^{72}$ /d. at 25.

${ }^{73} / d$. at 29.

${ }^{74}$ Id. at 28 .

${ }^{75}$ Id.

${ }^{76} / d$.
} 
registered in Italy, it may be possible for a single shareholder to bring an action against the directors. This is because, first, Art. 31, §5, of the proposal states that "the liability of directors shall be governed by the applicable national law." Second, Art. 2476, § 3, of the Italian Civil Code states that the action of liability against the directors is to be commenced by each quota holder, who can also request the issuance of a precautionary act of revocation of the directors in case of material breaches in the management of the company ${ }^{77}$.

\section{H. The Employee Participation}

The Proposal of 25 June 2008 does not regulate matters related to labor law, but regulates the employee involvement. The Proposal contains two articles on employee participation. The general provisions are contained in the art. 34. The arrangements for the participation of employees in the case of the transfer of the registered office of an SPE are written in the art. 38. The principle rule is that the SPE is covered by the law of the registered seat, if such a law exists. ${ }^{78}$

Art. 38 provides for a special regime where an SPE-one that is subject to employee participation-transfers its registered office to another Member State where (1) there is no or a lower level of employee participation rights or (2) which does not provide for employees of the SPE, situated in other Member States, the same entitlement to participation rights as they enjoyed before the transfer. ${ }^{79}$

In such cases, if at least one third of the SPE's employees are located in the home Member State, negotiations must take place between the management body and the representatives of the employees to reach an agreement on the their participation. ${ }^{80} \mathrm{In}$ the absence of an agreement, the participation arrangements existing in the home Member State shall be maintained. ${ }^{81}$

In the case of a cross-border merger of an SPE with an SPE or other company registered in another Member State, the provisions of the laws implementing the directive 2005/56/EC of 26 October 2005, on cross-border mergers of limited liability companies, shall apply. ${ }^{82}$

\footnotetext{
${ }^{77}$ Regarding this topic, see Zanarone, supra note 1, at 1047.

${ }^{78}$ Commission Proposal for a Council Regulation on the Statute for a European Private Company, supra note 2, at 29.

${ }^{79}$ Id. at 32-33.

${ }^{80}$ Id. at 33 .

${ }^{81} / d$.

${ }^{82}$ Council Directive 2005/56, 2005 O.J. (L 310) 1 (EC). See also id. at 29.
} 
With the rules of Proposal of 25 June 2008 it is easy to establish an employee participation free company; for instance a SPE, that has its registered office in the territory of Italy, is without regulation on employee participation. Participation arrangements only apply to SPEs that are registered in countries which provide for such arrangements. ${ }^{83}$ Only in the case of the transfer of the seat or of a cross-border merger, does the Proposal contain rules to protect the level of employee participation. ${ }^{84}$

The European Parliament on 10 March 2009 agreed to several amendments ${ }^{85}$ that repair some of the loopholes contained in the Proposal; space does not permit an analysis of each amendment. These amendments require, inter alia, that "appropriate safeguards should be put in place so that the SPE Statute cannot be used by large companies as a way to circumvent existing obligations under national and Community law." ${ }^{86}$ The intention is not to overburden small and medium-sized enterprises wishing to form an SPE for genuine business reasons. ${ }^{87}$

Regarding the issue of employee participation rights, the most difficult problem to resolve concerns the different traditions and arrangements in the national laws. Many States do not have such requirements applicable to their national private-limited liability companies, while others have expressed worries about the possible loss of rights acquired under national law, and that the use of SPE could undermine national employee participation requirements.

On this aspect, the principal outstanding issue for a compromise between States remains that of the threshold above which the proposal's foreseen rules on employee participation would apply. ${ }^{88}$

\footnotetext{
${ }^{83}$ Robbert van het Kaar \& Ilse Zaal, Employee Participation, in Zaman et. al. eds., The EUROPEAN Private Company (SPE) (note 2) 163.

${ }^{84}$ Id. at 159.

${ }^{85}$ See Resolution on the Proposal for a Council Regulation on the Statute for a European Private Company, supra note 32 .

${ }^{86}$ See id.

${ }^{87}$ See id.

${ }^{88}$ Proposal for a Council Regulation on a European Private Company - Political Agreement No. 16115/09 of 27 Nov. 2009, supra note 21.
} 